Joan-Lluís Capelleras

Universitat Autònoma de Barcelona (Spain)

Ignacio Contín-Pilart

INARBE, Universidad Pública de Navarra (Spain)

Martin Larraza-Kintana

INARBE, Universidad Pública de Navarra (Spain)

Victor Martin-Sanchez

King's College London (U.K.)

\title{
Regional and individual determinants of entrepreneurial growth aspirations
}

\begin{abstract}
This paper investigates the unique and joint effects of population density and early-stage entrepreneurs' human capital endowments (higher education, entrepreneurship training and owner-manager experience) on entrepreneurial growth aspirations. We test a number of hypotheses using data that combine individual and province level information in Spain over the period 2008-2010. We argue that growth aspirations of early-stage entrepreneurs are higher in more densely populated regions, but that such environmental influence is stronger for individuals with greater human capital. This is because they will be more aware that denser regions offer more favorable conditions for new businesses and also requires greater firm growth to compensate for a higher risk of business failure. Consistent with our view, we find that the growth aspirations of entrepreneurs with higher education are higher in densely populated provinces.
\end{abstract}

Keywords: Growth aspirations; Early-stage entrepreneurship; Population density; Human capital; Global Entrepreneurship Monitor (GEM)

Corresponding author: e-mail: victor.martin@kcl.ac.uk

Received 01 Nov 2016 - Accepted 26 Sept 2017

Note: Authors are listed alphabetically and contributed equally to this study

This is an Open Access article distributed under the terms of the Creative Commons Attribution-Non-Commercial-No Derivatives License (http://creativecommons.org/licenses/by-nc-nd/4.0/), which permits non-comercial re-use and distribution, provided the original work is properly cited, and is not altered or transformed in any way. 


\section{Introduction}

The aspiration of entrepreneurs to grow reflects their respective individual beliefs about the potential of their ventures (Levie and Autio 2013) ${ }^{1}$ and plays an important role to explain subsequent firm growth (Baum et al. 2001; Wiklund and Shepherd 2003; Davidsson et al. 2006; Capelleras and Hoxha 2010). This has led to an increasing interest in the antecedents of entrepreneurial growth aspirations. There is some evidence that external conditions and also the entrepreneur's background affect the formation of growth aspirations (Autio and Acs 2010; Autio et al. 2013; Estrin et al. 2013). Yet more study is required to develop a better understanding of how regional conditions affect growth aspirations, and particularly of how the regional context interacts with entrepreneur's individual characteristics to influence aspirations. The lack of knowledge on this latter topic is surprising when one considers that entrepreneurship itself results from the interplay between environmental conditions and individual attributes (Shane and Venkataraman 2000; Shane 2003; Grichnik et al. 2014). In this matter Kibler (2013) notices that "objective" regional conditions have an effect on cognitive processes, which in turn affect entrepreneurial growth aspirations. In this paper, we contribute to the emerging literature on the formation of entrepreneurial growth aspirations by analyzing the joint effect of environmental conditions and individual characteristics. Toward that end, we develop a framework for investigating the unique and joint effects of population density and entrepreneurs' human capital on the growth aspirations of early-stage entrepreneurs. This framework is mainly grounded on insights from the regional entrepreneurship literature and human capital theory.

\footnotetext{
${ }^{1}$ Researchers have used such terms as "growth intentions", "growth ambitions", and "growth aspirations" interchangeably (Levie and Autio 2013); however, we follow the current trend in this field of using the term "entrepreneurial growth aspirations" (see e.g. Autio and Acs 2010; Estrin et al. 2013).
} 
We first argue that the regional context in which a firm is created affects entrepreneurial growth aspirations. The role played by the regional environment in entrepreneurial activity is widely acknowledged in the entrepreneurship and economic geography literatures (e.g. Malecki 1997; Trettin and Welter 2011; Kibler 2013; Fotopoulos 2014). Although several regional factors have been shown to affect entrepreneurial growth aspirations, no study to date has considered the effect of population density. However, population density is a key region level variable as it determines not only the opportunity structure (on the demand side) but also the resources and abilities of individuals and their attitudes toward entrepreneurship (on the supply side). Hence, it captures features of the environment that are central to understanding entrepreneurial behavior and thereby the growth aspirations of entrepreneurs. Greater population density stimulates the creation of new firms owing to the consequent relatively high number of entrepreneurial opportunities to be discovered and exploited (Ucbasaran et al. 2008; Dencker et al. 2009; Dencker and Gruber 2014). But it also intensifies competition that leads to increases in the failure rate of businesses (Bosma et al. 2008; Kibler et al. 2014; Lööf and Nabavi 2014; Pe'er et al. 2014). Under these conditions of fierce competition in densely populated areas, prospective entrepreneurs may devise the need for a larger size of their new ventures. Therefore, greater opportunities and the higher size threshold would cause the growth aspirations of such entrepreneurs to be higher when population density is greater.

Second, and more importantly, we draw on the notion that "objective" characteristics of the regional environment interact with human capital (Kibler 2013) to shape entrepreneurial growth aspirations; thus, we examine how population density and the founder's knowledge endowments jointly affect entrepreneurial growth aspirations. We postulate that the relationship between population density and aspirations will be moderated by entrepreneurs' human capital. 
More specifically, we argue that their education and experience will play a key role in shaping how population density affects growth aspirations. Human capital gained through formal educational processes or previous experience allows entrepreneurs to gauge more accurately the environment's opportunities and threats, and greater human capital also increases the selfefficacy of entrepreneurs (Autio and Acs 2010). Overall, then, we expect that growth aspirations in regions with greater population density will be higher for those entrepreneurs with larger endowments of human capital. This is the main contribution of our study.

Our empirical analysis is based on a sample of 1835 early-stage entrepreneurs in Spain. We concur with the view of the Global Entrepreneurship Monitor (GEM) project and define an early-stage entrepreneur as an individual who is active in the process of starting a new firm for less than 42 months. The data set we employ combines individual-level information obtained from the GEM project in Spain with province-level information gathered from the Spanish Statistics Institute during the time period 2008-2010.

The rest of the paper is organized as follows. We start by developing and justifying four testable hypotheses; next we describe the data as well as our variables and methods used. After presenting the results of our empirical analysis, we conclude by discussing the implications of this research.

\section{Theory and hypotheses}

2.1 Population density and entrepreneurial growth aspirations

Individual behavior takes place in a particular location and in an environment, that is partly region specific (Fritsch and Storey 2014). Entrepreneurs exhibit a strong tendency to locate their respective businesses close to their place of residence (Figueiro et al. 2002; Dahl and Sorenson 2009), from which it follows that firm founders will be heavily influenced by the 
context of the region where they live. In this sense, researchers have shown that regional factors affect individual decisions in the entrepreneurial process (Mueller et al. 2008). Studies in the economic geography literature have found that such factors as population growth (Reynolds et al. 1994; Fritsch and Storey 2014), regional share of the labor force employed in small businesses (Fritsch 1997), and unemployment rates (Bosma and Schutjens 2011) all affect the rate at which new firms are created.

The conditions of the entrepreneur's immediate environment-for example, the economic, demographic, and physical features that constitute the regional context-are likely to shape aspirations (Kibler 2013). Because regions differ in their availability of resources and opportunities (Stam et al. 2012), individuals will encounter regional environments that are relatively more or less receptive to and supportive of an ambitious entrepreneur. So depending on the environmental conditions, individuals may aspire to different degrees of growth for their new businesses. However, not much is known about the regional influences on entrepreneurial growth aspirations.

In this paper, we focus on the regional level of population density as a potential determinant of entrepreneurial growth aspirations. Population density has previously been linked to higher rates of new business formation. In effect, more densely populated regions offer more local market opportunities related to the consumer market and more of the necessary inputs (Tödtling and Wanzenböck 2003; Wagner and Sternberg 2004) than do sparsely populated regions (Reynolds et al. 1994; Armington and Acs 2002), an advantage that attracts new firms and facilitates their entry. Densely populated regions are often also characterized by a more diverse population and more variety in demand, a combination that stimulates new firm start-ups (Frenken and Boschma 2007; Bosma et al. 2008). In addition, the conditions for entering a 
market are usually viewed as being more favorable in densely populated regions (Audretsch and Fritsch 1994) because of the closer proximity to a consumer market, the relatively more developed business infrastructure, and the presence of specialized suppliers and a more skilled workforce (Rotefoss and Kolvereid 2005; Pe'er et al. 2014). Networking and collaboration with potential customers, suppliers, and other organizations are also more likely to occur in regions with a greater population density (Liao and Welsch 2005; Kibler et al. 2014; Mole and Capelleras 2017). Together these various effects stimulate the creation of new firms in densely populated regions. That being said, entrepreneurial activities can be undermined in such regions by intense competition, high entry barriers, and the reduced leeway for product differentiation (Bosma et al. 2008; Kibler et al. 2014). Yet as Fritsch and Storey (2014) point out, there is a clear evidence of a positive impact of population density on the formation rate of both service and manufacturing businesses.

Continuing this line of work, we argue that population density affects not only new firm formation rates but also the growth aspirations of entrepreneurs. Access to greater and more diverse demand, resource availability, and the greater networking opportunities - all of which are associated with more densely populated regions - make for an environment that facilitates business growth ( $\mathrm{Li}$ et al. 2016). As already mentioned, however, business failure rates are higher in such regions (Lööf and Nabavi 2014) because of the associated strong competition (Bosma et al. 2008; Kibler et al. 2014); this downside will increase the perceived risk of business failure among entrepreneurs. In this highly competitive environment having a larger size may become essential for survival. New firms might seek to reach an efficient scale of operation to overcome their 'liability of smallness' that emerges from their lack of resources in comparison to their larger counterparts (Aldrich and Auster 1986; Stinchcombe 1965). A larger 
size also provides more visibility and may have a positive incidence on the social standing of both the firm and the entrepreneur (Chatterjee and Hambrick 2007; Autio et al. 2013). Visibility and prestige can, in addition, bring the benefit of improving the firm's access to resources, for example rising its capacity to attract, retain and motivate talented workers, or its ability to find financial support. As a result, individuals from highly populated regions will set a higher size threshold before initiating a new venture than do entrepreneurs from regions of lower population density.

Overall, we suggest that greater regional population density will have a positive impact on entrepreneurial growth aspirations owing to the expected higher growth potential of businesses in these regions and the required size threshold. Accordingly, we formulate our first hypothesis.

Hypothesis 1: The growth aspirations of entrepreneurs are higher in more densely populated provinces.

2.2 The moderating role of human capital

So far, we have argued that the regional context—more specifically, the region's population density - affects the growth aspirations of entrepreneurs. We now suggest that this effect will likely vary with the entrepreneur's endowments of human capital. Thus, our framework is based on the human capital approach (Becker 1964), together with insights from entrepreneurial cognition (Mitchell et al. 2002) and the so-called judgmental approach to entrepreneurship (Knight 1921; Mises 1949). Such approach views entrepreneurs as decision makers who invest resources based on their judgment of future conditions. The decisions entrepreneurs make are grounded in their beliefs or conjectures about the future, which are likely, we argue, to be influenced by their human capital. Following Becker (1964), we define human capital as knowledge and skills that individuals acquire through investments in education, on-the-job 
training, or other types of experience. ${ }^{2}$ According to Mitchell et al. $(2002,97)$, “entrepreneurial cognitions are the knowledge structures that people use to make assessments, judgments, or decisions involving opportunity evaluation, venture creation, and growth." Thus, entrepreneurial cognition concerns "how entrepreneurs use mental models to piece together unconnected information that may help them to assemble the necessary resources to launch and grow their businesses" (Mitchell et al. 2002, 97). In other words, entrepreneurial cognition links the human capital of knowledge and skill endowments with entrepreneurial judgment, which is understood to be the act of evaluating opportunities and deciding which resources must be assembled (and how they should be combined) so as to capitalize on entrepreneurial opportunities (Foss and Klein 2012).

Since entrepreneurial cognition is shaped by human capital and since judgment is an integral part of that cognition, it follows that entrepreneurs' understanding of conjectures about opportunities and threats in the environment — and ultimately about their respective ventures' future prospects - must be affected by their own endowments of human capital. Through work experience and various educational processes, individuals gain knowledge and build mental frames and models that are used to interpret and make sense of the reality surrounding them (Mitchell et al. 2002; Shepherd and DeTienne 2005; Gregoire et al. 2010). Education and experience influence how an entrepreneur perceives the environment; hence they affect opportunity identification and assessment and, ultimately, growth aspirations. Because human capital influences entrepreneurial cognition and judgment, it also affects how individuals

\footnotetext{
${ }^{2}$ Human capital attributes — including education, experience, knowledge, and skills — have long been identified as a critical resource for entrepreneurial success (see e.g. Sexton and Upton 1985; Pfeffer 1994; Florin et al. 2003), and empirical evidence has confirmed those positive relationships (Unger et al. 2011). In addition, other research has showed that human capital (and especially higher education) has a positive effect also on the aspirations of entrepreneurs (Autio and Acs 2010; Stam et al. 2012).
} 
perceive and understand their environment. A prime example is the shaping by human capital of entrepreneurs' aspirations about their firms' growth potential, as when entrepreneurs interpret "regional context" signals differently depending on their level of human capital. We therefore expect to observe differences in the growth aspirations of entrepreneurs within a given regional context as a function of their human capital endowments.

In this paper, we distinguish among three critical endowments of human capital: higher education, entrepreneurship training, and owner-manager experience. Entrepreneurs with higher education are expected either to embrace or to scale back ambitious growth targets in accordance with regional conditions (Dutta and Thornhill 2008; Capelleras et al. 2016). Recall that the higher risk of business failure in regions with greater population density, which is due mainly to greater competition (Pe'er et al. 2014), leads entrepreneurs to set a higher size threshold and thus to harbor higher growth aspirations. Highly educated entrepreneurs will naturally possess more general and also technical knowledge, which renders them better suited to gather, process, and analyze relevant information (Forbes 2005; Kim et al. 2006; Capelleras and Greene 2008). In addition, the knowledge gained through higher education may give entrepreneurs greater insight into the possible consequences of their decisions. Highly educated individuals may also have access to a large and resource-rich network of contacts (Batjargal 2003; Capelleras et al. 2010) that favors their awareness of changes in the local environmentincluding the recognition and exploitation of opportunities (Kibler et al. 2014). Early-stage entrepreneurs with higher education will thus be more aware of the advantages and disadvantages of densely populated regions; hence such individuals will be more likely to recognize that the competition in densely populated regions demands a higher growth rate threshold, so their growth aspirations will be higher. 
Previous research has found that the opportunity cost of being involved in entrepreneurial activities is greater for individuals with higher education because of their better job market prospects (Autio and Acs 2010). This finding accords with more highly educated entrepreneurs requiring higher growth potential of their ventures and therefore having higher growth aspirations. The opportunity cost dynamic is exacerbated in densely populated regions because there are usually more and better employment opportunities in those areas (Armington and Acs 2002; Bosma and Sternberg 2014: Hundt and Sternberg 2014). Even so, entrepreneurs with higher education also rate higher on self-efficacy (Autio and Acs 2010) - a trait that leads such individuals to suppose themselves capable of capitalizing on the greater growth opportunities typically associated with more densely populated regions (Bosma et al. 2008).

In sum, highly educated entrepreneurs in densely populated regions are expected to have higher growth aspirations than do entrepreneurs without higher education in the same regions. We express this notion formally as follows.

Hypothesis 2: The relationship between growth aspirations and population density varies with the educational level of the entrepreneur: the growth aspirations of entrepreneurs in more densely populated provinces are higher for those with higher education.

Individuals who have received training in entrepreneurship likewise exhibit higher growth aspirations in more densely populated regions. Entrepreneurship training focuses mainly on the identification of opportunities (Fiet and Barney 2002; DeTienne and Chandler 2004), and skills related to identifying highly credible opportunities can definitely be isolated and taught (Fiet and Barney 2002). Some evidence suggests that individuals who have received entrepreneurship training are more likely to undertake opportunity identification tasks than those who have not received such training (DeTienne and Chandler 2004). In other words, 
individuals can learn about opportunity-seeking processes via entrepreneurship training and, perhaps, thereby improve both the number of ideas generated and the innovativeness of those ideas.

We suggest that this focus on opportunities may affect an individual's understanding of the surrounding environment. Specifically, early-stage entrepreneurs who underwent entrepreneurship training will tend to use their specific knowledge to explore their immediate environment, search for new opportunities and choose to what extent grow their ventures. Therefore, they will be more aware that high-density regions offer better potential for growth and also that greater growth is required in such regions to compensate for the associated higher failure rates. It follows that those individuals who-while aware of the opportunities and risks associated with new ventures in densely populated regions-decide to create a new firm will demand higher growth rates and consequently have higher growth aspirations. Also, the learning process enabled by entrepreneurship training programs should have a positive effect on entrepreneurs' beliefs about their capacity to exploit the growth opportunities available in regions with greater population density (Autio and Acs 2010).

Thus, we expect entrepreneurs who have received entrepreneurship training and are located in regions with greater population density to hold higher growth aspirations than entrepreneurs without such entrepreneurship training located in the same regions. These considerations lead to our third hypothesis.

Hypothesis 3: The relationship between growth aspirations and population density varies with the extent of entrepreneurship training: the growth aspirations of entrepreneurs in more densely populated regions are higher for those with entrepreneurship training. 
Finally, we expect that also entrepreneurs who own or manage another established existing business will have higher growth aspirations in regions with greater population density. New firms suffer from the liability of newness: the greater propensity to fail as compared with established firms (Stinchcombe 1965; Aldrich and Wiedenmayer 1993). The liability of newness is attributable, in part, to skill gaps and lack of information. Therefore, human capital in general—and an individual's owner-manager experience in particular-should help reduce or eliminate that liability (Aldrich and Auster 1986).

Entrepreneurs with previous manager-owner experience have a "track record" as well as routines and established practices upon which they can rely to minimize the liability of newness and to develop a good understanding of their environment. They will be more likely to possess an organizing framework that facilitates the interpretation of data from the environment (Capelleras and Greene 2008; Kiss and Barr 2015). Consequently, individuals with prior experience will have different cognitive mechanism or mental models than others without such experience, which in turn will enable them to better process information they get from the environment that will influence, in our case, growth aspirations (Wood et al. 2014; Gruber et al. 2015). As discussed, it follows that entrepreneurs with prior owner-manager experience are more likely to recognize that a higher rate of growth is required in denser regions (Shepherd and DeTienne 2005). In addition, past owner-manager experience is likely to increase confidence about the possibility of making the most of growth opportunities available in regions with greater population density. We therefore expect entrepreneurs with prior owner-manager experience and located in more densely populated regions to have higher growth aspirations than entrepreneurs in the same location but without such experience. Thus, we have our last hypothesis. 
Hypothesis 4: The relationship between growth aspirations and population density varies with the entrepreneur's prior owner-manager experience: the growth aspirations of entrepreneurs in more densely populated provinces are higher for those with prior owner-manager experience.

Figure 1 offers a schematic summary of the paper's conceptual model.

Figure 1. Conceptual model and hypotheses

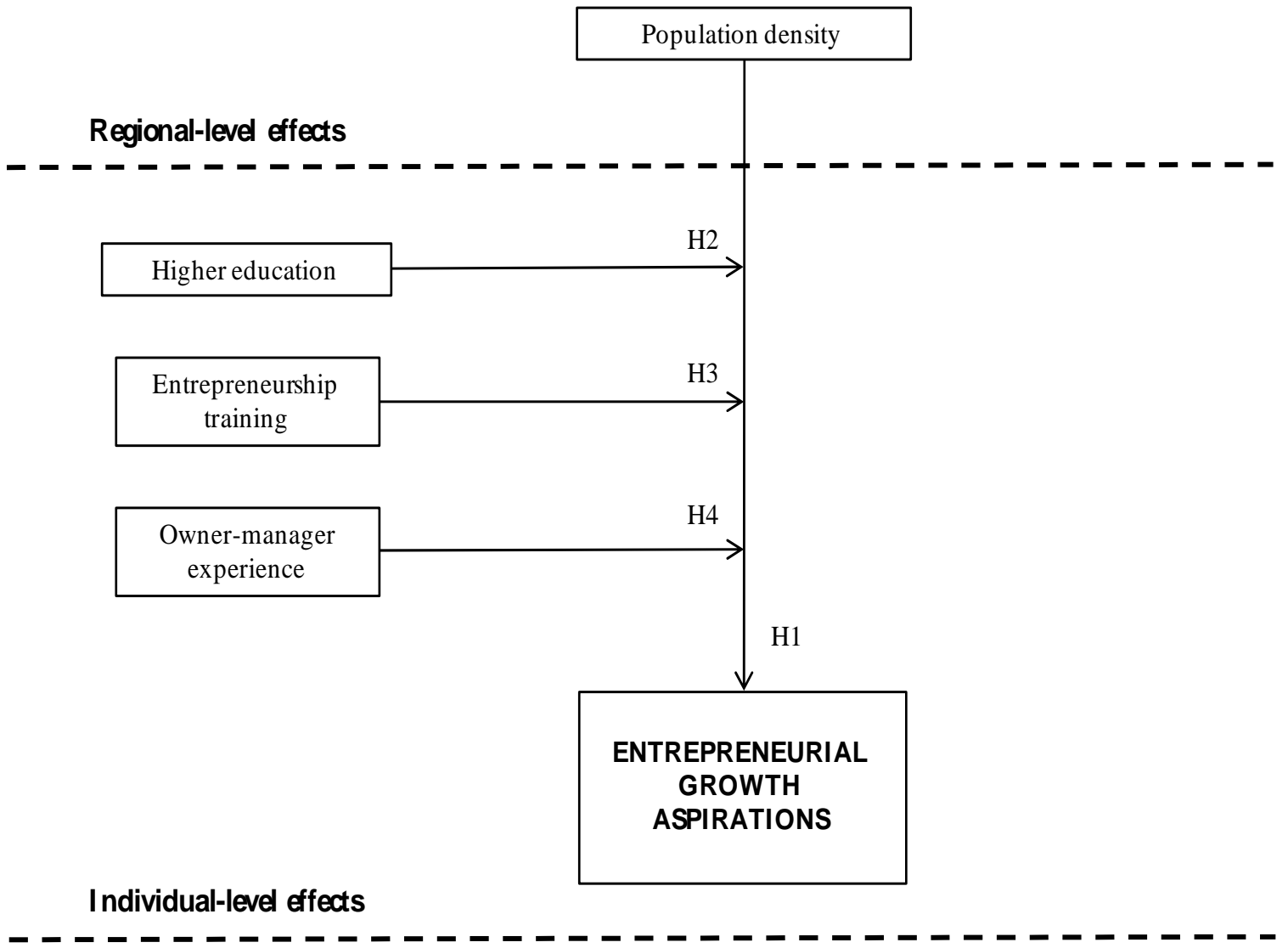

\section{Methods}

\subsection{Data and sample}

In testing the four hypotheses we employ two levels of analysis-namely, individual and regional levels. More specifically, our empirical model combines primary data on individuals 
in Spain and secondary data consisting of information at the province level. Our analysis covers the years 2008, 2009 and 2010.

Individual observations are obtained from the Adult Population Survey (APS) of the Spanish Global Entrepreneurship Monitor (GEM) project, which allows us to account for the characteristics of entrepreneurs who are in the process of starting up and managing a new business (Reynolds et al. 2005). The APS is designed to obtain a representative sample of the Spanish population aged 18 to 64. From the original APS database, we selected observations corresponding to early-stage entrepreneurs. That is, those entrepreneurs who own and manage a business that is less than 42 months old (Reynolds et al. 2005). After omitting observations for which there were any missing values and nonvalid answers, we are left with a sample of 1835 early-stage entrepreneurs.

Regional variables were collected from the Spanish Statistics Institute (Instituto Nacional de Estadística, INE) at the province level. The Spanish territory is divided into 52 provinces, which are the second-level territorial and administrative divisions and so correspond to "NUTS 3" under EUROSTAT classifications. We have confidence that the variables gathered from INE adequately capture the regional characteristics referenced in our study.

3.2 Variables and measures

Dependent variable. In accordance with our conceptual model, the dependent variable is entrepreneurial growth aspirations. Following previous studies (e.g. Estrin et al. 2013), we calculate entrepreneurs' growth aspirations as the difference between (the natural logarithms of) the entrepreneurs' expected number of employees in the next five years and the actual number of employees, exclusive of owners, at the firm's inception. 
Regional-level predictor. Prior work has found a link between population density and entrepreneurial activity (e.g. Keeble and Walker 1994; Reynolds et al. 1994; Brixy and Grotz 2007; Anyadike-Danes et al. 2005). To test our first hypothesis on the relationship between density and growth aspirations, we use the variable population density measured as the number of inhabitants per square kilometer $\left(\mathrm{km}^{2}\right)$ in each province and rounded to thousands for presentation purposes.

Cross-level interactions. With regard to human capital variables, we capture higher education with a dummy variable set equal to 1 if the entrepreneur has post-secondary (university degree) education and set equal to 0 otherwise. Entrepreneurship training is a dummy variable set equal to 1 if the entrepreneur has received some training activities related to starting an enterprise (and 0 otherwise). Finally, owner-manager experience takes the value 1 only for individuals who either own or manage another existing business.

Consequently, to test hypotheses 2,3 , and 4 , we create the following three cross-level interaction variables: population density $\times$ higher education; population density $\times$ entrepreneurship training, and population density $\times$ owner-manager experience. In these three cases, population density is mean-centered before the calculation of the interaction terms (Aiken and West 1991).

Individual-level controls. We control for entrepreneur age (in years) and gender $(1=$ male, $0=$ female). Opportunity perception is a measure of the entrepreneur's optimism (Cassar 2010). Specifically, it is a dummy variable set equal to 1 for entrepreneurs who perceived good opportunities to found a business within the next six months in the area where they live. We also control for fear of failure, a variable measuring whether that fear would discourage an entrepreneur from starting up a business, since this variable can be an important constraint for 
entrepreneurial activity (Vaillant and Lafuente 2007). Immigrants tend to exhibit lower levels of sociocultural fit (Contín-Pilart and Larraza-Kintana 2015), which affects their understanding of the environment and so may influence their aspirations. Hence Spanish nationality is an indicator variable set equal to 1 for entrepreneurs who were born in Spain and 0 otherwise. Another relevant control variable, particularly in the Spanish context, is necessity entrepreneurship, which takes value 1 if the business was created by necessity or 0 if it was as a consequence of opportunity motivation (Bolívar-Cruz et al. 2014; Justo et al. 2015).

Regional-level controls. We control for the annual unemployment rate change that is measured in terms of the change observed in the average unemployment rate from year $t-1$ to year $t$. Provincial unemployment rates (in percentage) are published every three months, so we compute the yearly average unemployment rate as the average of the four quarters' reported rates. The annual population change is based on the number of inhabitants in each province each year. As in the case of unemployment rates, the change is measured (in percentage) relative to the previous year's value. By calculating the relative change in these two variables, we account for the influence of the past on province-year individual current growth aspirations. Additionally, the $G D P / c$ denotes the gross domestic product per capita in each province and is given (for presentation purposes) in thousands of euros. We include time dummies to enable controlling for the years of the pool—while excluding one (here, 2008) as a reference category. Industry controls are also included in all our specifications to account for sectorial differences on growth aspirations (Estrin et al. 2013). Additionally, we have considered the potential influence of spillover effects of neighboring regions (Brixy and Grotz 2007; Kibler 2013). Specifically, we included the weighted average of population density and GDP/c of neighboring regions. None of the variables introduced to capture the spatial effects were significant, 
suggesting that spillover effects were negligible (Kibler 2013). For this reason and the sake of simplicity, we report the results without these latter variables.

\subsection{Methodological approach}

Our data set has a pooled cross-sectional time-series structure whereby individuals are hierarchically grouped by province. Because we are using two levels of analysis, data are analyzed using hierarchical linear modeling methods (Autio and Wennberg 2010; Estrin and Mickiewicz 2011; Autio et al. 2013; Estrin et al. 2013; Bosma and Sternberg 2014; Stuetzer et al. 2014). We do not employ standard multivariate methods because they would preclude our assuming the independence of observations (Hofmann et al. 2000; Autio and Wennberg 2010). In other words, those methods would require us to view individuals as acting homogenously but would not account for how the environment affects their decisions (Autio and Wennberg 2010).

To estimate the direct effect of population density on entrepreneurial growth aspirations, as well as the moderating effect of human capital endowments, we use a multilevel random effects specification (Autio et al. 2013; Estrin et al. 2013). Random effects analysis allows regression coefficients and intercepts to vary across provinces (Aguinis et al. 2011). In studies with more than one level of analysis, researchers have agreed that lower-level entities (e.g., individuals) are nested within higher-level ones (e.g., provinces) (Aguinis et al. 2013). This perspective has the advantage of facilitating multilevel analysis of cross-level interactions (Hundt and Sternberg 2014). In that sense, a multilevel random effects specification is more accurate than the multivariate methods (e.g., moderated multiple regressions) normally used in the management literature to estimate interaction effects (Aguinis et al. 2005). 
We adopt a three-step strategy for testing the direct effect of population density-and the moderating effect of human capital endowments - on entrepreneurial growth aspirations. First, we devise a "null model" for estimating between-province variance in order to ensure that both the intercept and the slope vary across provinces. Our observation of significant province-level variance mandates the use of multilevel techniques (model 1 in table 2). Next, we add individual and province-level controls (model 2 in table 2), and then the province-level predictor (model 3 in table 2). Finally, we add cross-level interactions to estimate the moderating effect (models 4, 5, 6 and 7 in table 2). The model we use to estimate both the direct effect of population density and the moderating effect of human capital endowments on entrepreneurial growth aspirations takes the following form (Snijders and Bosker 2004; Autio and Acs 2010; Autio et al. 2013; Stuetzer et al. 2014).

$\underline{\text { Individual-level component }}$

$$
\begin{aligned}
\log \left(\pi_{\mathrm{ij}}\right)_{\mathrm{t}} & =\beta_{0 \mathrm{j}} \\
& +\beta_{\mathrm{cj}}\{\text { individual-level controls } \mathrm{t}\} \\
& +\mathrm{r}_{\mathrm{ij}} .
\end{aligned}
$$

$\underline{\text { Regional-level component }}$

$$
\begin{aligned}
& \beta_{0 \mathrm{j}}=\gamma_{00}+\gamma_{01}\{\text { regional-level predictor } \mathrm{t}\}+\gamma_{02}\{\text { regional-level controls } \mathrm{t}\}+\mu_{0 \mathrm{j}}, \\
& \beta_{\mathrm{cj}}=\gamma_{\mathrm{p} 0}+\gamma_{\mathrm{p} 1}\{\text { regional-level predictor } \mathrm{t}\}+\gamma_{\mathrm{p} 2}\{\text { regional-level controls } \mathrm{t}\}+\mu_{\mathrm{pj}} .
\end{aligned}
$$

In this model, $\pi_{\mathrm{ij}}$ is a continuous measure of the growth aspirations chosen by individual $i$ in region $j$. As we use the logarithm to normalize this measure, then $\beta_{0 \mathrm{j}}$ is the coefficient for the effect of each individual—hierarchically nested in a specific province — on growth aspirations. $\beta_{\mathrm{cj}}$ are the coefficients for the individual-level variables. The term $\gamma_{00}$ is the mean of all intercepts (sometimes called the "constant"; Autio and Wennberg 2010) across provinces, and $\gamma_{\mathrm{p} 0}$ is the mean of all slopes across provinces. We use $\gamma_{01}$ and $\gamma_{02}$ to signify the coefficients for 
regional-level variables in the model 3; similarly, $\gamma_{\mathrm{p} 1}$ and $\gamma_{\mathrm{p} 2}$ are coefficients for the cross-level variables in models 4, 5, 6 and 7. Individual and regional-level residuals capture the setup's random aspect; we use $r_{i j}$ for the individual-level residuals and $\mu_{0 \mathrm{j}}$ and $\mu_{\mathrm{pj}}$ for regional-level ones. In other words, the variation in $\mu_{0 \mathrm{j}}$ and $\mu_{\mathrm{pj}}$ quantify the degree of heterogeneity in intercepts across provinces, and the variation in $\mathrm{r}_{\mathrm{ij}}$ quantifies the within-group variance (Aguinis et al. 2013). In sum, regional characteristics could affect individual-level regressions as a consequence of variation, at the individual level, in the intercepts and/or slopes across provinces.

In addition, we estimate the variance inflation factors for all our variables. The values range between 4.73 and 1.04, which indicates the absence of any serious multicollinearity problems. We follow the strictest standard by which values should be lower than 5 (Studenmund 1997). We remark that tolerance values are all above 0.1 , which further indicates that our variables do not suffer from multicollinearity (Autio et al. 2013). Finally, skewness and kurtosis test validate the univariate normality assumption.

\section{Results}

\subsection{Descriptive results}

Table 1 provides descriptive statistics and correlations; it shows that the average age of individuals in the sample is 40 years and that almost $60 \%$ of them are men. Most entrepreneurs (63\% of the sample) do not view the next six months as a good opportunity to set up a new venture in their area. This may be due to the economic downturn that the Spanish economy suffered during our period of analysis. The overwhelming majority $(88 \%)$ of individuals was born in Spain. A total of $17 \%$ indicate that their entrepreneurial activity is driven by necessity. 


\section{Journal of Evolutionary Studies in Business JESB}

Volume 3, Number 1, 17-53, January-June 2018

doi:10.1344/jesb2018.1.j036

Table 1. Descriptive statistics and correlation matrix

\begin{tabular}{|c|c|c|c|c|c|c|c|c|c|c|c|c|c|c|c|c|}
\hline & Mean & S.D. & 1 & 2 & 3 & 4 & 5 & 6 & 7 & 8 & 9 & 10 & 11 & 12 & 13 & 14 \\
\hline $\begin{array}{l}\text { 1. Entrepreneurial growth } \\
\text { aspirations (Ln) }\end{array}$ & 0.46 & 0.65 & 1.000 & & & & & & & & & & & & & \\
\hline 2. Age & 39.85 & 10.65 & $-0.109 * * *$ & 1.000 & & & & & & & & & & & & \\
\hline 3. Gender & 0.60 & 0.48 & $0.062^{* *}$ & -0.017 & 1.000 & & & & & & & & & & & \\
\hline 4. Opportunity perception & 0.37 & 0.48 & $0.161^{* * *}$ & -0.009 & $0.052^{* *}$ & 1.000 & & & & & & & & & & \\
\hline 5. Fear of failure & 0.32 & 0.46 & $-0.070^{* *}$ & 0.014 & $-0.088^{* * *}$ & $-0.129^{* * *}$ & 1.000 & & & & & & & & & \\
\hline 6. Spanish nationality & 0.88 & 0.31 & $-0.051^{* *}$ & 0.024 & $0.025 *$ & $-0.067^{* * *}$ & 0.023 & 1.000 & & & & & & & & \\
\hline 7. Necessity entrepreneurship & 0.17 & 0.37 & $-0.040^{*}$ & $0.051^{* * *}$ & $-0.047^{* *}$ & $-0.069 * * *$ & $0.068^{* * *}$ & 0.014 & 1.000 & & & & & & & \\
\hline 8. Higher education & 0.33 & 0.47 & $0.090^{* * *}$ & $-0.074^{* * *}$ & -0.002 & $0.039 * *$ & $-0.059 * * *$ & $-0.028 *$ & $-0.026^{*}$ & 1.000 & & & & & & \\
\hline 9. Entrepreneurship training & 0.36 & 0.48 & $0.086^{* * *}$ & $-0.045^{* *}$ & 0.024 & -0.015 & $-0.044^{* *}$ & -0.023 & -0.005 & $0.136^{* * *}$ & 1.000 & & & & & \\
\hline 10. Owner-manager experience & 0.11 & 0.31 & $-0.082^{* * *}$ & $0.110^{* * *}$ & 0.003 & $0.039 * *$ & $-0.048^{* *}$ & $0.047^{* *}$ & -0.015 & -0.007 & $-0.060 * * *$ & 1.000 & & & & \\
\hline $\begin{array}{l}\text { 11. Annual unemployment rate } \\
\text { change (in percentage units) }\end{array}$ & 0.36 & 0.25 & $-0.089 * * *$ & -0.015 & 0.022 & $-0.028^{*}$ & -0.008 & $-0.039^{* *}$ & $-0.059^{* * *}$ & -0.015 & $0.053^{* * *}$ & $-0.030^{* *}$ & 1.000 & & & \\
\hline $\begin{array}{l}\text { 12. Annual population change } \\
\text { (\%) }\end{array}$ & 1.52 & 1.07 & -0.027 & $-0.025^{*}$ & -0.012 & $0.075^{* * *}$ & -0.010 & $-0.075^{* * *}$ & $-0.073 * * *$ & -0.016 & $-0.156^{* * *}$ & $0.075^{* * *}$ & $0.413^{* * *}$ & 1.000 & & \\
\hline 13. GDP/c ( $€$ in thousands) & 23.47 & 4.51 & -0.034 & 0.024 & -0.008 & $0.072^{* * *}$ & $-0.060^{* * *}$ & $-0.068^{* * *}$ & $-0.067^{* * *}$ & $0.059 * * *$ & -0.008 & 0.023 & -0.022 & $0.207^{* * *}$ & 1.000 & \\
\hline $\begin{array}{l}\text { 14. Population density } \\
\text { (inhab } / \mathrm{km}^{2} \text { in thousands) }\end{array}$ & 0.33 & 0.74 & $0.097^{* * *}$ & $-0.049 * *$ & 0.018 & 0.025 & -0.015 & -0.010 & -0.023 & 0.008 & $0.044^{* *}$ & -0.003 & $-0.182^{* * *}$ & $0.157^{* * *}$ & $0.030^{*}$ & 1.000 \\
\hline
\end{tabular}

${ }^{*} p<0.1,{ }^{* *} p<0.05,{ }^{* * *} p<0.001$

Online ISSN: 2385-7137

http://revistes.ub.edu/index.php/JESB
COPE Committee on Publication Ethics

Creative Commons License 4.0 @creative 
With regard to the human capital variables, the table shows that $33 \%$ of the entrepreneurs have higher education qualifications (university degree), nearly $36 \%$ of them consist of individuals who have received entrepreneurship training, and $11 \%$ are accounted as owners or managers of another existing business.

Turning to the regional variables, the average population density is 336.38 inhabitants per $\mathrm{km}^{2}$. The unemployment rate increased (on average) $36.6 \%$ annually at the provincial level, which reveals how hard the Spanish economy was hit by the economic crisis. The annual population change is about $1.52 \%$ inhabitants, and the average GDP per capita (all provinces) is about $€ 23,470$.

Bivariate correlations indicate that entrepreneurial growth aspirations are positively related to population density, entrepreneurs' education, and entrepreneurship training. However, there is a negative association between growth aspirations and owner-manager experience.

\subsection{Multilevel model results}

Table 2 reports results from multilevel random intercept models predicting entrepreneurial growth aspirations. Model 1 devises the "null model" to estimate between-province variance in order to ensure that both intercept and the slope vary across provinces. Our observation of significant provincial-level variable mandates the use of multilevel techniques. Model 2 provides results for the individual and regional-level control variables. Model 3 incorporates the effects of the regional predictor and thus shows the influence of population density on entrepreneurial growth aspirations. In support of hypothesis 1, the values describe a positive relationship between those two variables.

In all models we find that highly educated entrepreneurs are more likely to have higher growth aspirations than the rest of entrepreneurs. 
Table 2. Multilevel random intercept model predicting entrepreneurial growth aspirations

\begin{tabular}{|c|c|c|c|c|c|c|c|}
\hline & Model 1 & Model 2 & Model 3 & Model 4 & Model 5 & Model 6 & Model 7 \\
\hline \multicolumn{8}{|l|}{ Individual-level controls } \\
\hline Age & & $\begin{array}{l}-0.0069 * * * \\
(0.0011)\end{array}$ & $\begin{array}{l}-0.0069 * * * \\
(0.0012)\end{array}$ & $\begin{array}{l}-0.0068 * * * \\
(0.0011)\end{array}$ & $\begin{array}{l}-0.0069 * * * \\
(0.0012)\end{array}$ & $\begin{array}{l}-0.0069 * * * \\
(0.0012)\end{array}$ & $\begin{array}{l}-0.0068 * * * \\
(0.0011)\end{array}$ \\
\hline Gender & & $\begin{array}{l}0.0119 \\
(0.0415)\end{array}$ & $\begin{array}{c}0.0129 \\
(0.0415)\end{array}$ & $\begin{array}{l}0.0150 \\
(0.0409)\end{array}$ & $\begin{array}{l}0.0125 \\
(0.0410)\end{array}$ & $\begin{array}{l}0.0124 \\
(0.0416)\end{array}$ & $\begin{array}{l}0.0141 \\
(0.0408)\end{array}$ \\
\hline Opportunity perception & & $\begin{array}{l}0.1888^{* * * *} \\
(0.0439)\end{array}$ & $\begin{array}{l}0.1903^{* * * *} \\
(0.0434)\end{array}$ & $\begin{array}{l}0.1903^{* * * *} \\
(0.0430)\end{array}$ & $\begin{array}{l}0.1887 * * * \\
(0.0426)\end{array}$ & $\begin{array}{l}0.1902 * * * \\
(0.0434)\end{array}$ & $\begin{array}{l}0.1887 * * * \\
(0.0424)\end{array}$ \\
\hline Fear of failure & & $\begin{array}{l}0.0193 \\
(0.0446)\end{array}$ & $\begin{array}{l}0.0216 \\
(0.0449)\end{array}$ & $\begin{array}{l}0.0219 \\
(0.0450)\end{array}$ & $\begin{array}{c}0.0232 \\
(0.0452)\end{array}$ & $\begin{array}{l}0.0220 \\
(0.0449)\end{array}$ & $\begin{array}{l}0.0235 \\
(0.0454)\end{array}$ \\
\hline Spanish nationality & & $\begin{array}{l}-0.0266 \\
(0.0599)\end{array}$ & $\begin{array}{l}-0.0248 \\
(0.0597)\end{array}$ & $\begin{array}{l}-0.0296 \\
(0.0580)\end{array}$ & $\begin{array}{l}-0.0253 \\
(0.0580)\end{array}$ & $\begin{array}{l}-0.0245 \\
(0.0596)\end{array}$ & $\begin{array}{l}-0.0293 \\
(0.0565)\end{array}$ \\
\hline Necessity entrepreneurship & & $\begin{array}{l}-0.0277 \\
(0.0611)\end{array}$ & $\begin{array}{l}-0.0249 \\
(0.0617)\end{array}$ & $\begin{array}{l}-0.0255 \\
(0.0610)\end{array}$ & $\begin{array}{l}-0.0230 \\
(0.0613)\end{array}$ & $\begin{array}{l}-0.0245 \\
(0.0616)\end{array}$ & $\begin{array}{l}-0.0234 \\
(0.0606)\end{array}$ \\
\hline Higher education & & $\begin{array}{l}0.0804 * * \\
(0.0327)\end{array}$ & $\begin{array}{l}0.0797 * * \\
(0.0327)\end{array}$ & $\begin{array}{l}0.0883^{* * *} \\
(0.0284)\end{array}$ & $\begin{array}{l}0.0797 * * \\
(0.0329)\end{array}$ & $\begin{array}{l}0.0800 * * \\
(0.0328)\end{array}$ & $\begin{array}{l}0.0881 * * \\
(0.0285)\end{array}$ \\
\hline Entrepreneurship training & & $\begin{array}{l}0.1132 * * \\
(0.0423)\end{array}$ & $\begin{array}{l}0.1146^{* * *} \\
(0.0422)\end{array}$ & $\begin{array}{l}0.1159 * * \\
(0.0420)\end{array}$ & $\begin{array}{l}0.1233 * * \\
(0.0381)\end{array}$ & $\begin{array}{l}0.1145 * * \\
(0.0422)\end{array}$ & $\begin{array}{l}0.1237 * * \\
(0.0379)\end{array}$ \\
\hline Owner-manager experience & & $\begin{array}{l}-0.0709 \\
(0.0439)\end{array}$ & $\begin{array}{l}-0.0718 * \\
(0.0435)\end{array}$ & $\begin{array}{l}-0.0754^{*} \\
(0.0436)\end{array}$ & $\begin{array}{l}-0.0722 * \\
(0.0434)\end{array}$ & $\begin{array}{l}-0.0779 * \\
(0.0413)\end{array}$ & $\begin{array}{l}-0.0818 * * \\
(0.0410)\end{array}$ \\
\hline \multicolumn{8}{|l|}{ Regional-level controls } \\
\hline Annual unemployment rate change (t-1) & & $\begin{array}{l}-0.0003 \\
(0.1238)\end{array}$ & $\begin{array}{c}0.0343 \\
(0.1214)\end{array}$ & $\begin{array}{c}0.0289 \\
(0.1204)\end{array}$ & $\begin{array}{c}0.0220 \\
(0.1215)\end{array}$ & $\begin{array}{c}0.0290 \\
(0.1223)\end{array}$ & $\begin{array}{c}0.0128 \\
(0.1217)\end{array}$ \\
\hline Annual population change (t-1) & & $\begin{array}{c}0.0171 \\
(0.0275)\end{array}$ & $\begin{array}{c}0.0098 \\
(0.0265)\end{array}$ & $\begin{array}{c}0.0113 \\
(0.0262)\end{array}$ & $\begin{array}{c}0.0117 \\
(0.0265)\end{array}$ & $\begin{array}{c}0.0104 \\
(0.0265)\end{array}$ & $\begin{array}{c}0.0136 \\
(0.0262)\end{array}$ \\
\hline $\mathrm{GDP} / \mathrm{c}$ & & $\begin{array}{l}-0.0077 \\
(0.0049)\end{array}$ & $\begin{array}{l}-0.0101 * * \\
(0.0043)\end{array}$ & $\begin{array}{l}-0.0104 * * \\
(0.0042)\end{array}$ & $\begin{array}{l}-0.0102 * * \\
(0.0043)\end{array}$ & $\begin{array}{l}-0.0099 * * \\
(0.0043)\end{array}$ & $\begin{array}{l}-0.0104 * * \\
(0.0043)\end{array}$ \\
\hline \multicolumn{8}{|l|}{ Regional-level predictor } \\
\hline Population density (H1) & & & $\begin{array}{l}0.1518^{* *} \\
(0.0634)\end{array}$ & $\begin{array}{c}0.1001 * \\
(0.0566)\end{array}$ & $\begin{array}{c}0.1077 * \\
(0.0588)\end{array}$ & $\begin{array}{l}0.1548 * * \\
(0.0636)\end{array}$ & $\begin{array}{c}0.0662 \\
(0.0608)\end{array}$ \\
\hline $\begin{array}{l}\text { Cross-level interaction } \\
\text { Population density } * \text { Higher education } \\
(\mathrm{H} 2)\end{array}$ & & & & $\begin{array}{l}0.1556 * * \\
(0.0637)\end{array}$ & & & $\begin{array}{l}0.1473 * * \\
(0.0590)\end{array}$ \\
\hline $\begin{array}{l}\text { Population density } * \text { Entrepreneurship } \\
\text { training }(\mathrm{H} 3)\end{array}$ & & & & & $\begin{array}{l}0.1217 \\
(0.0797)\end{array}$ & & $\begin{array}{l}0.109 \\
(0.0726)\end{array}$ \\
\hline $\begin{array}{l}\text { Population density * Owner-manager } \\
\text { experience }(\mathrm{H} 4)\end{array}$ & & & & & & $\begin{array}{l}-0.0654 \\
(0.0813)\end{array}$ & $\begin{array}{l}-0.0664 \\
(0.0815)\end{array}$ \\
\hline \multicolumn{8}{|l|}{ Random effects parameters } \\
\hline Intercept & $\begin{array}{l}0.4722 * * * \\
(0.0231)\end{array}$ & $\begin{array}{l}0.6451 * * * \\
(0.1564)\end{array}$ & $\begin{array}{l}0.6777 * * * \\
(0.1436)\end{array}$ & $\begin{array}{l}0.7374 * * * \\
(0.1421)\end{array}$ & $\begin{array}{l}0.7347 * * * \\
(0.1452)\end{array}$ & $\begin{array}{l}0.7299 * * * \\
(0.1482)\end{array}$ & $\begin{array}{l}0.7362 * * * \\
(0.1425)\end{array}$ \\
\hline Variance of random intercept & $\begin{array}{l}0.0131 * * \\
(0.0047)\end{array}$ & $\begin{array}{l}0.0092^{* * *} \\
(0.0035)\end{array}$ & $\begin{array}{l}0.0054^{* * *} \\
(0.0043)\end{array}$ & $\begin{array}{l}0.0052^{* * * *} \\
(0.0045)\end{array}$ & $\begin{array}{l}0.0054 * * \\
(0.0045)\end{array}$ & $\begin{array}{l}0.0055^{* *} * \\
(0.0043)\end{array}$ & $\begin{array}{l}0.0053^{* * *} \\
(0.0047)\end{array}$ \\
\hline Variance of overall residual & $\begin{array}{l}0.4072 \\
(0.0351)\end{array}$ & $\begin{array}{c}0.3607 \\
(0.0241)\end{array}$ & $\begin{array}{l}0.3615 \\
(0.0241)\end{array}$ & $\begin{array}{l}0.3610 \\
(0.0242)\end{array}$ & $\begin{array}{c}0.3611 \\
(0.0241)\end{array}$ & $\begin{array}{l}0.3614 \\
(0.0241)\end{array}$ & $\begin{array}{l}0.3606 \\
(0.0242)\end{array}$ \\
\hline Industry fixed effects & Yes & Yes & Yes & Yes & Yes & Yes & Yes \\
\hline Years fixed effects & Yes & Yes & Yes & Yes & Yes & Yes & Yes \\
\hline$N$ of observations & 2116 & 1835 & 1835 & 1835 & 1835 & 1835 & 1835 \\
\hline$N$ of groups (provinces) & 51 & 51 & 51 & 51 & 51 & 51 & 51 \\
\hline Wald chi-squared & - & $153.42 * * *$ & $147.60 * * *$ & $244.46^{* * *}$ & $192.19 * * *$ & $352.60 * * *$ & $783.79 * * *$ \\
\hline Log-likelihood & -2442.0037 & -1991.9429 & -1989.2362 & -1987.5111 & -1988.1462 & -1989.1328 & -1986.5165 \\
\hline $\begin{array}{l}\text { Degrees of freedom } \\
\text { AIC }^{a}\end{array}$ & 0 & 17 & 18 & 19 & 19 & 19 & 21 \\
\hline
\end{tabular}

Notes: Reported values are non-standardized $\beta$ coefficients. Robust standard errors are given in parentheses. ${ }^{\mathrm{a}}$ AIC is Akaike's information criterion $=2 k-2 \mathrm{x}(\log$ likelihood), where $k$ indicates the degrees of freedom. $* p<0.10$, $* * p<0.05, * * * p<0.001$; two-tailed significance. 
This result is consistent with previous research in this topic (Autio and Acs 2010). Entrepreneurship training is also positively related to aspirations. In contrast, results show that experienced entrepreneurs are more likely to have lower growth aspirations.

Model 4 of table 2 examines the cross-level interaction between population density and higher education. In line with hypothesis 2 , we find that the positive effect of population density observed in model 3 varies as a function of the entrepreneur's higher education level, a result that holds in the full model as well (model 7). While in all models entrepreneurship training is positively related to aspirations, neither model 5 nor model 7 support hypothesis 3 by which the relationship between population density and entrepreneurial growth aspirations varies with the incidence of entrepreneurship training. Finally, model 6 does not provide support for hypothesis 4 . We find that the positive effect of population density observed in model 3 does not seem to vary with the entrepreneur's owner-manager experience; this result holds in the full model (model 7). A clear implication of these findings is that higher education (but not ownermanager experience nor entrepreneurship training) may lead to entrepreneurs understanding more completely the benefits and risks of new ventures into a densely populated region.

To gauge these results more precisely, we next present the corresponding interaction plot. Figure 2 depicts the interaction effect — on growth aspirations - of population density and higher education. Observe that, consistently with our prediction, the relationship between population density and growth aspirations changes with entrepreneurs' educational level. In particular, growth aspirations in densely populated provinces tend to increase with the educational attainment of entrepreneurs. 
Figure 2. Moderating effect of higher education on the relationship between population density and entrepreneurial growth aspirations

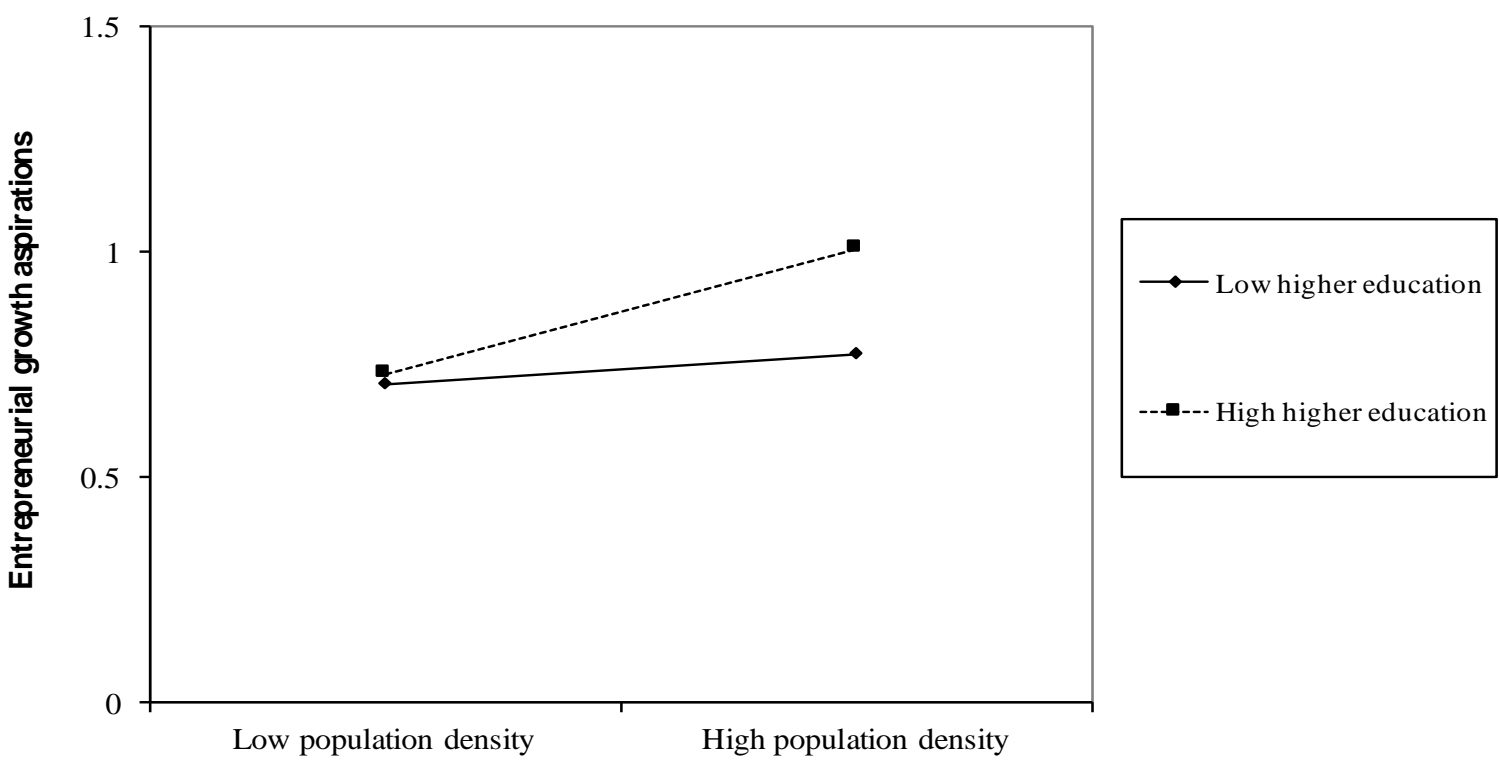

We find several control variables to be statistically significant. Not surprisingly, entrepreneurs who are younger, and also those who see good opportunities for starting a business in the area where they live, have higher growth aspirations. One of the regional variables, GDP per capita, has a negative effect on aspirations, a result that is consistent with the view that high growth opportunities for entrepreneurs are available in developing economies and regions (Estrin et al. 2013).

\subsection{Robustness tests}

Given that growth aspirations are observed only for those individuals who have been identified as early-stage entrepreneurs, it could be that self-selection into entrepreneurship has biased our findings. In other words, there might be unobservable characteristics of the individual (e.g. ability, motivation, (risk) preferences) that influenced her decision to become an entrepreneur, 
which might be also correlated with her growth aspirations afterwards. Neglecting this potential self-selection bias may produce unreliable estimations.

To address this issue, we apply a two-step Heckman selection model as follows. First, we estimate the probability of entering entrepreneurship (the first-stage or "selection" equation). As an exclusion restriction, we include in this equation a variable that is correlated with the decision of entering entrepreneurship, yet uncorrelated with the outcome variable of interest (growth aspirations). Specifically, we use a variable that captures the entrepreneur's social capital, which in GEM data corresponds to a dummy variable indicating whether or not the focal individual personally knows another entrepreneur who has initiated a start-up venture within the last two years. The validity of this exclusion restriction is confirmed by our further analysis. Second, we estimate the growth aspirations equation (the second-stage or "outcome" equation) and introduce in the set of regressors the Inverse Mills Ratio obtained from the estimation of the first stage. We do not detect any significant selection bias arising from the possibility that the unobservable factors determining the decision to become an entrepreneur also determine the entrepreneur's employment growth aspirations. Accordingly, the conclusions from our hypothesis testing do not change once we address potential biases caused by individuals' self-selection into entrepreneurship (Autio et al. 2013; Estrin et al. 2013). With the purpose of assessing the robustness of our results, we also estimate a model replacing our central regional predictor variable (population density) with the percentage of people living in highly urbanized areas within the province. This can be considered an indicator of urbanization as it captures general benefits of locating in dense regions (Reynolds et al. 1994; Bosma et al. 2008; Goerlich Gisbert and Cantarino Martí 2015). The results show that this variable has a positive impact on entrepreneurial growth aspirations and, thus, are consistent 
with those presented above on the positive relationship between population density and aspirations. Detailed results for our robustness tests, though not formally reported here, are available from the authors upon request.

\section{Discussion and conclusions}

This paper contributes to the knowledge about the formation of entrepreneurial growth aspirations by examining two under-researched but important issues: (1) the unique effects of regional population density, and (2) the joint effects of population density and founder characteristics. We have used a rich data set that combines individual data on early-stage entrepreneurs taken from the Spanish GEM Adult Population Survey with regional data from the Spanish Statistic Institute. Our research extends prior research to show not only the tight connection between overall regional conditions and individual growth aspirations but also that this connection depends on the human capital of these entrepreneurs. Our results thus underscore the importance of higher education.

Our research yields a number of important insights. First, we confirm our expectation that regional population density has a positive effect on the growth aspirations of early-stage entrepreneurs. This result highlights the importance to new businesses of local demand and of access to resources, since entrepreneurs evidently do assess whether their surrounding environment offers them the opportunity to initiate a venture. Furthermore, the higher size threshold required in densely populated areas would have a positive effect on growth aspirations during the first few years of a new business. We conclude that the regional context affects not only entrepreneurs' start-up decisions, as shown by extensive previous research (e.g., Malecki 1997; Mueller et al. 2008; Bosma and Schutjens 2011; Trettin and Welter 2011; Kibler 2013; Kibler et al. 2014), but also their aspirations as indicated by this study. 
Second, this paper shows that the positive effect of population density on entrepreneurial growth aspirations is partly shaped by the human capital endowments of entrepreneurs. We observe in particular that the effect of population density on growth aspirations varies with the higher education of the entrepreneur. As hypothesized, the joint effect of higher education and population density also has a positive effect on entrepreneurial aspirations. Therefore, we find support for the notion that university-level education provides entrepreneurs with the knowledge and frame of mind conducive to recognizing that a higher required size threshold is required in densely populated regions to compensate for the greater risk of business failure.

Third, our results indicate that owner-manager experience does not moderate the relationship between population density and entrepreneurial growth aspirations. However, we find that such experience has a direct negative effect on aspirations. This result is interesting as it opens the floor to question about the accuracy of entrepreneurial growth aspirations. Are the aspirations of experienced entrepreneurs more accurate and realistic than those entrepreneurs without experience? Clearly, they have first-hand valuable information concerning the difficulties and prospects of new ventures. But also, we should take into account that the experienced managers and/or entrepreneurs have experienced the recent economic downturn (remember that our observations cover the 2008-2010 period). Witnessing and suffering these negative environmental conditions leads them to an excess of caution and even to pessimism about the prospects of their ventures?

Fourth, our results indicate that entrepreneurship training has a positive effect on growth aspirations. Indeed, the resource-based theory of the firm suggests that the recognition of opportunities, a skill that can be learned via entrepreneurship training, is a distinctive ability of individuals (Alvarez and Busenitz 2001; Brush et al. 2001). Yet we unexpectedly find that the 
joint effect of population density and entrepreneurship training is not statistically significant. The knowledge and skills related to opportunity identification and exploitation, which individuals can gain through entrepreneurship training, should allow trained entrepreneurs to discover and exploit promising entrepreneurial opportunities and also to recognize the greater size threshold required in densely populated environments. The data, however, seem not to support this account. We might surmise that an individual with entrepreneurial training holds higher growth aspirations regardless of the context — or at least irrespective of the region's population density. The question is: What drives this attitude? Does entrepreneurial training facilitate the discovery of opportunities even in less favorable environments? Maybe, and contrary to the case of entrepreneurs with managerial and/or entrepreneurial experience, such unremittingly high aspirations simply reflect overconfidence (Koellinger et al. 2007). Future research should address these questions because the answers are of considerable practical importance to those involved in entrepreneurship training (e.g., business schools, governmental agencies). As in the case of experienced entrepreneurs, additional research is needed to assess how realistic are the growth aspirations of those who receive entrepreneurship training; in the meantime, one should not disregard the extent to which such training might nurture an excess of self-confidence in entrepreneurial abilities.

Moreover, these differences in how individuals with different types of human capital adjust their entrepreneurial growth aspirations to environmental conditions (in our case to population density) prove that different individuals react in different ways to the same stimulus coming from the environment that surrounds all of them. Therefore, it is worth to continue investigating how the different features of those individuals, like their human capital, shape individual responses to environment stimuli. 
This study has some limitations, which open opportunities for relevant future research. Our research is based on data for a single country. A useful extension would be to test our conceptual model on the determinants of growth aspirations with data from other countries. And notwithstanding the value of examining cross-level interactions among factors at the individual and regional level, future research should extend this approach by incorporating national-level determinants.

The binary character of some of our key variables may also be seen as a limitation. As indicated we use primary data obtained by the GEM project in Spain. Binary variables in these large questionnaires are often included to simplify data gathering process and subsequent coding. The need for simplicity is reinforced by GEM's global character: binary scales help minimize bias due to cultural interpretations (Autio et al. 2013) and also reduce problems of translation equivalence (Ter Hofstede et al. 2002). We remark that our moderating variables (higher education, entrepreneurship training, and owner-manager experience) are measured as binary outcomes for the reasons just presented. Interesting insights could be gained if future research accounts for the nature of higher education and the type of training (e.g., voluntary or compulsory) while also distinguishing clearly between entrepreneurial and manager experience.

In our analyses, we have taken the individual endowments of human capital as given, and have looked at how reactions, in the form of entrepreneurial growth aspirations, to environmental conditions vary across the heterogeneity (in terms of human capital) of entrepreneurs in the region. Nonetheless, it may be argued that those environmental conditions may also have some influence on the human capital levels of the inhabitants in a region. For example, there might be different levels of spatial mobility among entrepreneurs according to their human capital 
endowments. In the particular case of Spain, however, this is unlikely to happen because regional mobility rates are among the lowest in the European Union (Bonin et al. 2008). In addition, it could be added that the aggregate levels of human capital may have a say in the environmental conditions. These complex bidirectional influences between individual and environment need to be explored in the future in order to reach a better understanding of the environment-individual nexus and its effect on entrepreneurial action.

In sum, this paper has analyzed and documented for the first time how the population density of the region in which the entrepreneur is located influences the growth aspirations of these entrepreneurs. Entrepreneurs in more densely populated regions hold greater growth aspirations. However, the educational level of the entrepreneur plays an important role in shaping how the entrepreneur understands this environment and consequently how the characteristics of such environment, such as population density, impact entrepreneurial growth aspirations.

\section{Acknowledgements}

The authors acknowledge financial support from projects ECO2013-46954-C3-1-R, ECO2013-46954C3-2-R, ECO2013-48496-C4-2-R and ECO2013-48496-C4-4-R (Spanish Ministry of Economics and Competitiveness). We also thank the GEM project for its support to this research.

\section{References}

Aguinis, Herman, James C. Beaty, Robert J. Boik, and Charles A. Pierce. 2005. "Effect size and power in assessing moderating effects of categorical variables using multiple regression: A 30-year review." Journal of Applied Psychology 90:94-107.

Aguinis, Herman, Ryan K. Gottfredson, and Steven A. Culpepper. 2013. "Best-Practice Recommendations for Estimating Cross-Level Interaction Effects Using Multilevel Modeling." Journal of Management 39 (6): 1490-1528.

Aguinis, Herman, Ryan K. Gottfredson, and Thomas A. Wright. 2011. "Best-practice recommendations 
for estimating interaction effects using meta-analysis." Journal of Organizational Behavior 32: 1033-1043.

Aiken, Leona S., and Stephen G. West. 1991. Multiple regression: Testing and interpreting interactions. Newbury Park, London: Sage.

Aldrich, Howard E., and Ellen R. Auster. 1986. "Even dwarfs started small: liabilities of age and size and their strategic implications." Research in Organizational Behavior 8:165-198.

Aldrich, Howard E., and Gabriele Wiedenmayer. 1993. "From traits to rates: an ecological perspective on organizational foundings." In Advances in entrepreneurship, firm emergence, and growth, edited by Katz, J., and R. Brockhaus, 145-195. Greenwhich, CT: JAI Press.

Alvarez, Sharon, A., and Lowell W. Busenitz. 2001. "The entrepreneurship of resource-based theory." Journal of Management 27 (6): 755-775.

Anyadike-Danes, Michael, Mark Hart, and Maureen O'Reilly. 2005. "Watch that space! The county hierarchy in firm births \& deaths in the UK, 1980-1999." Small Business Economics 25:273-292.

Armington, Catherine, and Zoltan J. Acs. 2002. "The determinants of regional variation in new firm formation." Regional Studies 36:33-45.

Audretsch, David B., and Michael Fritsch. 1994. "The geography of firm births in Germany." Regional Studies 28 (4): 359-365.

Autio, Erkko, and Zoltan J. Acs. 2010. "Intellectual property protection and the formation of entrepreneurial growth aspirations." Strategic Entrepreneurship Journal 4:234-251.

Autio, Erkko, Saurav Pathak, and Karl Wennberg. 2013. "Consequences of cultural practices for entrepreneurial behaviors." Journal of International Business Studies 44:334-362.

Autio, Erkko, and Karl Wennberg. 2010. "You think, therefore, I become: Social attitudes and the transition to entrepreneurship." Paper presented at the DRUID summer conference, London, June 16-18.

Batjargal, Bat. 2003. "Social capital and entrepreneurial performance in Russia: A longitudinal study." Organization Studies 24:535-556.

Baum, J. Robert, Edwin A. Locke, and Ken G. Smith. 2001. "A multidimensional model of venture growth.” Academy of Management Journal 44 (2): 292-303.

Becker, Gary S. 1964. Human capital. Chicago: University of Chicago Press.

Bolívar-Cruz, Alicia, Rosa M. Batista-Canino, and Esther Hormiga. 2014. "Differences in the perception and exploitation of entrepreneurial opportunities by immigrants." Journal of Business Venturing Insights (1-2): 31-36.

Bonin, Holger, Werner Eichhorst, Christer Florman, Mette Okkels Hansen, Lena Skiöld, Jan Stuhler, Konstantinos Tatsiramos, Henrik Thomasen, and Klaus F. Zimmermann. 2008. "Geographic 
mobility in the European Union: Optimising its social and economic benefits." IZA Research Report 19.

Bosma, Niels, and Veronique Schutjens. 2011. "Understanding regional variation in entrepreneurial activity and entrepreneurial attitude in Europe." The Annals of Regional Science 47:711-742.

Bosma, Niels, André van Stel, and Kashifa Suddle. 2008. "The geography of new firm formation: evidence from independent start-ups and new subsidiaries in the Netherlands." International Entrepreneurship and Management Journal 4:129-146.

Bosma, Niels, and Rolf Sternberg. 2014. "Entrepreneurship as an Urban Event? Empirical Evidence from European Cities." Regional Studies 48:1016-1033.

Brixy, Udo, and Reinhold Grotz. 2007. "Regional patterns and determinants of birth and survival of new firms in Western Germany." Entrepreneurship and Regional Development 19:293-312.

Brush, Candida G., Patricia G. Greene, Mark Hart, and Harold S. Haller. 2001. "From initial idea to unique advantage: the entrepreneurial challenge of constructing a resource base." Academy of Management Executive 15 (1): 64-78.

Capelleras, Joan-Lluís, and Francis J. Greene. 2008. "The determinants and growth implications of venture creation speed." Entrepreneurship and Regional Development 20 (4): 311-337.

Capelleras, Joan-Lluís, and Durim Hoxha. 2010. "Start-up size and subsequent firm growth in Kosova: the role of entrepreneurial and institutional factors." Post-Communist Economies 22:411-426.

Capelleras, Joan-Lluís, Francis J. Greene, Hugo Kantis, and Rodrigo Rabetino. 2010. "Venture creation speed and subsequent growth: Evidence from South America." Journal of Small Business Management 48 (3): 302-324.

Capelleras, Joan-Lluís, Ignacio Contín-Pilart, Martin Larraza-Kintana, and Victor Martin-Sanchez. 2016. "Unemployment and growth aspirations: the moderating role of education." Strategic Change 25:169-183.

Cassar, Gavin. 2010. "Are individuals entering self-employment overly-optimistic? An empirical test of plans and projections on nascent entrepreneur expectations." Strategic Management Journal 31 (8): 822-840.

Chatterjee, Arijit, and Donald C. Hambrick. 2007. "It's all about me: Narcissistic chief executive officers and their effects on company strategy and performance." Administrative Science Quarterly 52:351-386.

Contín-Pilart, Ignacio, and Martin Larraza-Kintana. 2015. "Do entrepreneurial role models influence the nascent entrepreneurial activity of immigrants?" Journal of Small Business Management 53 (4): 1146-1163.

Dahl, Michael S., and Olav Sorenson. 2009. "The embedded entrepreneur." European Management 
Review 6:172-181.

Davidsson, Per, Leona Achtenhagen, and Lucia Naldi. 2006. "What do we know about small firm growth?" In The life cycle of entrepreneurial ventures, edited by Parker, S., 361-398. New York: Springer.

Dencker, John, and Marc Gruber. 2014. "The Effects of Opportunities and Founder Experience on New Firm Performance.” Strategic Management Journal 36:1035-1052.

Dencker, John, Marc Gruber, and Sonali K. Shah. 2009. "Individual and opportunity factors influencing job creation in new firms." Academy of Management Journal 52:1125-1147.

DeTienne, Dawn R., and Gaylen N. Chandler. 2004. "Opportunity identification and its role in the entrepreneurial classroom: a pedagogical approach and empirical test." Academy of Management Learning and Education 3:242-257.

Dutta, Dev K., and Stewart Thornhill. 2008. "The evolution of growth intentions: toward a cognitionbased model." Journal of Business Venturing 23:307-332.

Estrin, Saul, Julia Korosteleva, and Tomasz Mickiewicz. 2013. "Which institutions encourage entrepreneurial growth aspirations?" Journal of Business Venturing 28:564-580.

Estrin, Saul, and Tomasz Mickiewicz. 2011. "Institutions and female entrepreneurship.” Small Business Economics 37 (4): 397-415.

Fiet, James O., and Jay Barney. 2002. The systematic search for entrepreneurial discoveries. New York: Quorum.

Figueiro, Octávio, Paulo Guimaraes, and Douglas Woodward. 2002. "Home-field advantage: locations decisions of Portuguese entrepreneurs." Journal of Urban Economics 52:341-361.

Florin, Juan, Michael Lubatkin, and William Schulze. 2003. "A social capital model of high growth ventures." Academy of Management Journal 46 (3): 374-384.

Forbes, Daniel P. 2005. "Managerial Determinants of Decision Speed in New Ventures." Strategic Management Journal 26:355-366.

Foss, Nicolai J., and Peter G. Klein. 2012. Organizing entrepreneurial judgment. Cambridge: Cambridge University Press.

Fotopoulos, Georgios. 2014. "On the spatial stickiness of UK new firm formation rates." Journal of Economic Geography 14:651-679.

Frenken, Koen, and Ron A. Boschma. 2007. "A theoretical framework for evolutionary economic geography: industrial dynamics and urban growth as a branching process." Journal of Economic Geography 7 (5): 635-649.

Fritsch Michael. 1997. "New firms and regional employment change." Small Business Economics 9:437-448. 
Fritsch, Michael, and David J. Storey. 2014. "Entrepreneurship in a regional context: Historical roots, recent developments and future challenges." Regional Studies 48 (6): 939-954.

Goerlich Gisbert, Francisco J., and Isidro Cantarino Martí. 2015. "Estimaciones de la población rural y urbana a nivel municipal." Estadística Española 57 (186): 5-28.

Gregoire, Denis A., Pamela S. Barr, and Dean A. Shepherd. 2010. "Cognitive processes of opportunity recognition: the role of structural alignment." Organization Science 21:413-431.

Grichnik, Dietmar, Jan Brinckmann, Luv Singh, and Sophie Manigart. 2014. "Beyond environmental scarcity: Human and social capital as driving forces of bootstrapping activities." Journal of Business Venturing 29:310-326.

Gruber, Marc, Sung Min Kim, and Jan Brinckmann. 2015. "What is an attractive business opportunity? An empirical study of opportunity evaluation decisions by technologists, managers, and entrepreneurs." Strategic Entrepreneurship Journal 9:205-225.

Hofmann, David A., Mark A. Griffin, and Mark B. Gavin. 2000. "The application of hierarchical linear modeling to organizational research." In Multilevel Theory, Research, and Methods in Organizations: Foundations, Extensions, and New Directions, edited by Klein, K. J., and S. W. J. Kozlowski, 467-511. San Francisco: Jossey-Bass.

Hundt, Christian, and Rolf Sternberg. 2014. "Explaining new firm creation in Europe from a spatial and time perspective: A multilevel analysis based upon data of individuals, regions and countries." Papers in Regional Science 95 (2): 223-257.

Justo, Rachida, Dawn R. DeTienne, and Philipp Sieger. 2015. "Failure or voluntary exit? Reassessing the female underperformance hypothesis." Journal of Business Venturing 30 (6): 775-792.

Keeble, David, and Sheila Walker. 1994. "New firms, small firms and dead firms: spatial patterns and determinants in the United Kingdom.” Regional Studies 28:411-427.

Kibler, Ewald. 2013. "Formation of entrepreneurial intentions in a regional context." Entrepreneurship and Regional Development 35 (3-4): 293-323.

Kibler, Ewald, Teemu Kautonen, and Matthias Fink. 2014. "Regional social legitimacy of entrepreneurship: Implications for entrepreneurial intention and start-up behaviour." Regional Studies 48 (6): 995-1015.

Kim, Phillip, Howard E. Aldrich, and Lisa A. Keister. 2006. “Access (not) denied: The impact of financial, human, and cultural capital on entrepreneurial entry in the United States." Small Business Economics 27 (1): 5-22.

Knight, Frank H. 1921. Risk, uncertainty and profit. New York: August M. Kelley.

Kiss, Andreea N., and Pamela S. Barr. 2015. "New venture strategic adaptation: The interplay of belief structures and industry context." Strategic Management Journal 36:1245-1263. 
Koellinger, Philipp, Maria Minniti, and Christian Schade. 2007. "I think I can, I think I can...: a study of entrepreneurial behavior." Journal of Economic Psychology 28:502-527.

Levie, Jonathan, and Erkko Autio. 2013. Growth and growth intentions. Enterprise Research Centre White Paper.

Li, Minghao, Stephan J. Goetz, Mark Partridge, and David A. Fleming. 2016. "Location determinants of high-growth firms." Entrepreneurship and Regional Development 28 (1-2): 97-125.

Liao Jianwen, and Harold Welsch. 2005. "Roles of social capital in venture creation: key dimensions and research implications." Journal of Small Business Management 43:345-362.

Lööf, Hans, and Pardis Nabavi. 2014. "Survival, productivity and growth of new ventures across locations." Small Business Economics 43:477-491.

Malecki, Edward J. 1997. "Entrepreneurs, networks, and economic development: a review of recent research." In Advances in entrepreneurship, firm emergence and growth., edited by Katz, J. A., 57-118. London: JAI Press.

Mises, Ludwig von. 1949. Human actions: A treatise on Economics. New Haven, CT: Yale University Press.

Mitchell, Ronald K., Lowell Busenitz, Theresa Lant, Patricia P. McDougall, Eric A. Morse, and J. Brock Smith. 2002. "Toward a theory of entrepreneurial cognition: Rethinking the people side of entrepreneurship research.” Entrepreneurship Theory and Practice 27:93-104.

Mole, Kevin M., and Joan-Lluís Capelleras. 2017. "Take-up and variation of advice for new firm founders in different contexts." Environment and Planning C: Politics and Space. DOI: $10.1177 / 2399654417691514$.

Mueller Pamela, André van Stel, and David J. Storey. 2008. "The effects of new firm formation on regional development over time: the case of Great Britain." Small Business Economics 30:59-71.

Pe'er, Aviad, Ilan Vertinsky, and Thomas Keil. 2014. "Growth and survival: The moderating effects of local agglomeration and local market structure.” Strategic Management Journal 36 (3): 541-564.

Pfeffer, Jeffrey. 1994. Competitive advantage through people. Boston: Harvard Business School Press. Reynolds, Paul, Niels Bosma, Erkko Autio, Steve Hunt, Natalia De Bono, Isabel Servais, Paloma LopezGarcia, and Nancy Chin. 2005. "Global Entrepreneurship Monitor: Data Collection Design and Implementation 1998-2003." Small Business Economics 24:205-231.

Reynolds, Paul, David J. Storey, and Paul Westhead. 1994. "Cross-national comparisons of the variation in new firm formation rates." Regional Studies 28 (4): 443-456.

Rotefoss, Beate, and Lars Kolvereid. 2005. "Aspiring, nascent and fledgling entrepreneurs: an investigation of the business start-up process." Entrepreneurship and Regional Development 17:109-127. 
Sexton, Donald L., and Nancy Bowman. 1985. "The entrepreneur: a capable executive and more." Journal Business Venturing 1:129-140.

Shane, Scott. 2003. A general theory of entrepreneurship: The individual-opportunity nexus. Cheltenham, UK: Edward Elgar.

Shane, Scott, and Sankaran Venkataraman. 2000. "The promise of entrepreneurship as a field of research." Academy of Management Review 25:217-226.

Shepherd, Dean A., and Dawn R. DeTienne. 2005. "Prior knowledge, potential financial reward, and opportunity identification.” Entrepreneurship Theory and Practice 29:91-112.

Snijders, Tom A.B., and Roel J. Bosker. 2004. Multilevel analysis: An introduction to basic and advanced multilevel modeling. London: Sage.

Stam, Erik, Niels Bosma, Arjen van Witteloostuijn, Jeroen de Jong, Sandy Bogaert, Nancy Edwards, and Ferdinand Jaspers. 2012. Ambitious Entrepreneurship: A Review of the Academic Literature and Directions for Public Policy (1-162). Den Haag: Advisory Council for Science and Technology Policy.

Stinchcombe, Arthur L. 1965. "Social structures and organizations." In Handbook of Organizations, edityed by March, J. G. 142-193. Chicago: Rand McNally.

Studenmund, A. H. 1997. Using Econometrics. A Practical Guide (Addison-Wesley).

Stuetzer, Michael, Martin Obschonka, Udo Brixy, Rolf Sternberg, and Uwe Cantner. 2014. "Regional characteristics, opportunity perception and entrepreneurial activities." Small Business Economics 42:221-244.

Ter Hofstede, Frenkel, Michel Wedel, and Jan-Benedict E. M. Steenkamp. 2002. "Identifying spatial segments in international markets." Marketing Science 21 (2): 160-177.

Trettin, Lutz, and Friederike Welter. 2011. "Challenges for spatially oriented entrepreneurship research." Entrepreneurship and Regional Development 23 (7-8): 575-602.

Tödtling, Franz, and Herta Wanzenböck. 2003. "Regional differences in structural characteristics of start-ups." Entrepreneurship and Regional Development 15:351-370.

Ucbasaran, Deniz, Paul Westhead, and Mike Wright. 2008. "Opportunity Identification and Pursuit: Does an Entrepreneur's Human Capital Matter?” Small Business Economics 30:153-173.

Unger, Jens M., Andreas Rauch, Michael Frese, and Nina Rosenbusch. 2011. "Human capital and entrepreneurial success: A meta-analytical review." Journal of Business Venturing 26:341-358.

Vaillant, Yancy, and Esteban Lafuente. 2007. "Do different institutional frameworks condition the influence of local fear of failure and entrepreneurial examples over entrepreneurial activity?" Entrepreneurship \& Regional Development 19:313-337.

Wagner, Joachim, and Rolf Sternberg. 2004. "Start-up activities, individual characteristics, and the 


\section{Journal of Evolutionary Studies in Business}

regional milieu: lessons for entrepreneurship support policies from German micro data." The Annals of Regional Science 38:219-240.

Wiklund, Johan, and Dean Shepherd. 2003. "Aspiring for, and Achieving Growth: The Moderating Role of Resources and Opportunities." Journal of Management Studies 40:1919-1941.

Wood, Matthew S., Alexander McKelvie, and J. Michael Haynie. 2014. "Making it personal: opportunity individuation and the shaping of opportunity beliefs." Journal of Business Venturing 29:252-272.

This is an Open Access article distributed under the terms of the Creative Commons Attribution-Non-Commercial-No Derivatives License (http://creativecommons.org/licenses/by-nc-nd/4.0/), which permits non-comercial re-use and distribution, provided the original work is properly cited, and is not altered or transformed in any way. 